\title{
Profitability of organic and conventional cow-calf operations under Swedish conditions
}

\author{
Pernilla Salevid • Karl-Ivar Kumm
}

Received: 5 April 2012 /Accepted: 12 November 2012 /Published online: 9 December 2012

(C) The Author(s) 2012. This article is published with open access at Springerlink.com

\begin{abstract}
In order to maintain the high natural values of Swedish semi-natural pasture, suckler cow numbers must increase, but numbers are more likely to decrease due to low profitability, changes to the EU support system and increasing wage levels. This study sought to identify production models for cow-calf operations with sufficient profitability to pay at least stipulated farm workers wage. In the calculations, the income from weaned calves and EU support was reduced by operating costs, excluding labour. The surplus was divided by hours spent on labour, resulting in a return to labour per hour. The calculations were carried out in varying future scenarios where the Common Agricultural Policy is changing. The results showed that organic production models created a higher return to labour than conventional production models. One reason for this is the environmental payment for organic farming. Another reason is that organic production maintains more acreage, equalling higher environmental payments and other EU support per suckler cow. Other more profitable production models included spring calving, heavy cows and winter feed based on silage. Some organic production models gave a return to labour above the stipulated farm workers wage. However, if the single farm payment scheme is phased
\end{abstract}

P. Salevid $(\bowtie) \cdot$ K.-I. Kumm

Department of Animal Environment and Health, Swedish University of Agricultural Sciences,

Skara, Sweden

e-mail: pernilla.salevid@slu.se out and not replaced by an increase in environmental payments, the return to labour will be at best half the stipulated farm workers wage.

Keywords Semi-natural pasture Cow-calf .

Organic $\cdot$ Profitability $\cdot$ Future scenarios

\section{Introduction}

Since 1995, when Sweden joined the EU, the number of dairy cows has decreased by 134,000 , while the number of suckler cows has increased by 40,000 (Swedish Board of Agriculture 2011a). Therefore, the total number of cows, and hence calves available for meat production, has decreased. Total Swedish beef production decreased from 140,000 $\mathrm{t}$ in 1995 to 131,000 t in 2010 (Swedish Board of Agriculture 2011a). Consumption of beef in Sweden increased during the same period from 163,000 to $239,000 \mathrm{t}$ (Swedish Board of Agriculture 2011b). As a result, the degree of self-sufficiency in beef has decreased from 85 to $56 \%$ since Sweden became a member of the EU.

The Swedish Environmental Objectives require national biodiversity to be maintained at the current level and used in a sustainable way. In order to do so, an existing agricultural sector with grazing animals is needed (Ministry of Agriculture 2010). Suckler cows are therefore very important for reaching the Swedish Environmental Objectives, especially the objective 
stating that 450,000 ha of semi-natural pasture be kept open for grazing (Swedish Environmental Objectives 2011). After a long period of decreasing semi-natural pasture area, the grazing acreage began to increase in 1995, when the current environmental payment system was introduced, until 2005, when the acreage started to decrease again, most likely due to a lack of grazing animals. In 2010, the semi-natural pasture acreage was 420,000 ha (Swedish Board of Agriculture 2011a), of which 160,000 ha are grazed by suckler cows and heifers (SCB 2010).

One goal for the Swedish Rural Development Programme is to have $20 \%$ of agricultural land in quality-assured organic production by 2013 (Swedish Board of Agriculture 2010a). In 2010, the proportion of certified agricultural land was $14 \%$ (Swedish Board of Agriculture 2011c). A large proportion of Swedish suckler cow production is organic. According to one survey, $37 \%$ of the nation's suckler cow operations receive environmental support for organic farming. Of the suckler cow operations with more than 100 cows, $70 \%$ are organic (SCB 2010). The differences between organic and conventional cow-calf operations include a ban on pesticides and commercial mineral fertilisers and restricted use of veterinary medicines and concentrate feeds, which may result in lower yields, a need for lower stocking rates per hectare and longer grazing periods (KRAV 2012).

The Swedish agricultural acreage is only $8 \%$ of the total land mass. The suitability for farming varies greatly throughout the country. In areas favourable for arable farming, the proportion of agricultural land is $25 \%$ (Ministry of Agriculture 2010). In other parts of the country with less favourable conditions, specifically the forested districts, there is continuous abandonment of both semi-natural pasture and arable land. In these areas, the landscape is characterised by relatively small fields and grazing, interspersed with lakes and forest. In the forest districts in Götaland (Gsk) and lower parts of Norrland $(\mathrm{Nn})$, the agricultural acreage has decreased by $30 \%$ since the Second World War and the remaining farming operations are more or less $100 \%$ grazing and forage-based animal production (Swedish National Atlas 2011) with low profitability (Agriwise 2011). Continuing farming operations in these regions are important in reaching the Swedish Environmental Objective of 'A varied agriculture landscape' (Swedish Environmental Objectives
2011). For this to occur, suckler cow operations are essential.

From the viewpoint of the Swedish Environmental Objectives, organic farming practices have several advantages compared with conventional farming. The ban on the use of pesticides and rapidly soluble mineral fertilisers and the requirement for a larger proportion of leys in the crop rotation are some of these advantages. Farming without mineral fertilisers decreases emissions of climate gases and eutrophying effluents. Crop rotations with leys increase the biological diversity in the landscape (Nilsson 2007). These advantages have resulted in an organic grant of 1,800 SEK suckler cow $^{-1}$ year ${ }^{-1}$ (including replacement heifer), according to the Rural Development Programme in Sweden for 2007-2013 (Swedish Board of Agriculture 2011c). Cow-calf operations (both conventional and organic) deliver on these objectives and can assure long-term sustainable use of agricultural land as semi-natural pasture and arable land in forest-dominated regions are part of the ecosystem.

Swedish organic cow-calf operations are held in high esteem by consumers because the criteria on animal welfare in the organic regulations are more in line with natural cattle behaviour and because suckler cows with calves graze large areas of semi-natural pasture. In 2008, Swedish consumers were willing to pay $4.50 \mathrm{SEK} \mathrm{kg}^{-1}$, or $18 \%$ above the ordinary price of prime beef, for this service (Swedish Board of Agriculture 2010a). In spite of this, many organically raised suckler calves are sold to conventional fattening operations without any added value for the organic status. Of Swedish cattle stocks, $8 \%$ are qualityassured organic (Ekoweb 2012) in accordance with the KRAV certification programme for organic production (KRAV 2012). Only $4 \%$ of the prime beef slaughtered in 2006 was KRAV-assured (Swedish Board of Agriculture 2008). The sale of any type of organic meat is below $2 \%$ of total meat consumption. However, the sale of branded meat, often locally branded, has increased from 9 to $19 \%$ during the same period (SCB 2011).

According to Agribeef (2011), there are profitable cow-calf operations in regions with high levels of environmental payments and other EU support, combined with favourable biological production conditions. Farm businesses with low levels of support and/or low biological production have very poor 
profitability. The fact that many of these farmers still carry on with their operations suggests that they treat the decoupled single farm payments as an enterprisespecific income from beef, despite the fact that they would receive the payment for arable land regardless of whether they have cows or any other form of production. The payment should therefore be seen as a common income. According to regional calculations preformed by the Swedish University of Agricultural Sciences based on feasible achievements under efficient Swedish conditions, the revenue from grazingbased beef production can cover short-term operating costs but not stipulated farm workers wage, investments in buildings or capital needs (Agriwise 2011). The Ministry of Agriculture (2004) concluded that there was a greater risk of decreased beef production in Sweden compared with other EU countries due to the shorter vegetation period, higher official specifications on farm buildings, the small-scale structure of most Swedish beef production, a lack of large interconnected grazing areas and a high level of labour cost per hour.

The future for cow-calf operations in Sweden is uncertain. In 2012, the male premium of around 1,300 SEK bull $^{-1}$ and 1,900 SEK steer ${ }^{-1}$ was abolished. If this is not compensated for, by a higher price at slaughter, the price for calves sold from cow-calf operations will most probably decline. OECD-FAO (2011) has projected a price level decline for beef in the years leading up to 2020, which would decrease revenue even more. A possible decrease in the single farm payment would also negatively affect cow-calf operations, since these systems utilise large areas of land. In a future study by the Swedish Board of Agriculture (2007), a decrease in Swedish beef production and grazing acreage was predicted. This could have a variety of causes, including a decrease in EU support, deregulation of world trade in agricultural products and competition for agricultural land from the bioenergy market.

In order to ensure that there is a new generation of farmers willing to continue with beef production and to invest in new buildings when old buildings are run down, a return to labour comparable to the stipulated farm workers wage and a market level return on invested capital are likely prerequisites. An expert panel consisting of beef producers, farm advisors and researchers in genetics and nutrition interviewed in a Delphi study implied that in order to achieve such profitability in suckler cow beef production, organic production with environmental support and a higher price on beef is needed. Alternatively, a large-scale conventional production system for overwintering cows outdoors could achieve the cost differential needed. Both systems require access to large areas of interconnected semi-natural pasture for grazing. Above average fertility rates, growth rates and feed conversion rates are in themselves insufficient to reach the profitability goals, according to the expert panel (Salevid 2011). The purpose of the present study was to examine whether future organic and conventional cow-calf operations can achieve a stipulated farm workers wage and a return on investment of $5 \%$ under Swedish conditions.

\section{Method and premises for calculations}

\section{Method of calculation}

The sum of enterprise-specific income minus the sum of long-term operating costs, excluding the cost of labour, was calculated per cow and year for a number of different production models comprising 100 suckler cows in varying future scenarios. The result was divided by the labour requirement for animal husbandry and management of the grazing land, to give a return to labour per hour for these tasks. The sum of enterprise-specific income included the sales revenue for weaned calves (bull calves and heifer calves not used for replacement), a proportion of the cull cows, environmental grants for semi-natural pasture and leys, support for less favoured areas and, in some cases, the single farm payment. In other words, this is the income that will appear when starting up a cowcalf operation and that will disappear if it ceases. Long-term operating costs included feed, fencing, bedding, breeding bull, contractor, insurance, depreciation and maintenance of buildings, opportunity costs for land and interest on animal, building and working capital. Again, these were the costs that would be incurred when starting up a cow-calf operation and that would disappear when it ceases. It was assumed that all labour used in growing and harvesting the winter feed was supplied by a contractor paid the full market price.

The data used on calf output per cow are average survey data for breeding herds (Swedish Dairy 
Association 2011). Labour demand per cow per year was based on survey data from large herds (Nelson 2002). Feed demand (Clason 2009) and cost of feed production (Kumm 2009) and buildings (Häggström et al. 2005) were based on engineering data. The feed demand was based on theoretical nutritional needs. Taking all this into account gave better production results than the average for existing smaller cow-calf herds and also allowed future possibilities for economically sustainable models to be calculated.

Other data such as prices, support payments and other costs are typical farm data from 2009, collected from the Swedish Board of Agriculture and the Swedish University of Agricultural Sciences (Agriwise), including the stipulated wage of $180 \mathrm{SEK} \mathrm{h}^{-1}$ plus employer contributions. Details of the data collection are given in the footnotes of Table 4 .

Calculations were made for: (1) various production areas with different natural conditions and (2) various possible future scenarios. The scenarios were chosen based on the fact that prices and politics will change during the depreciation period, averaging 15 years, for farm buildings and their inventory. The scenarios included abolition of the single farm payments scheme, changes in the environmental payments and a decrease in the market value of weaned calves as a result of the abolition of the male premium. The calculations were based on the fact that the single farm payments on arable land can be perceived by the farmer as a common income independent of production or an enterprise-specific income for suckler cows. In the sensitivity analyses, returns to labour were calculated for changes in building costs, rationalisation by scaling up and a price premium for organic beef, resulting in an increase in calf prices. The calculations were carried out for three regions with various natural opportunities, but in all cases with fairly weak conditions for profitable agriculture and hence a greater risk of farm closure and associated loss of nature and landscape values. These regions were forest districts in Gsk, plain districts in Svealand (Ss) and the lower parts of Nn. Together, these regions contain $60 \%$ of the suckler cows and $57 \%$ of the semi-natural pasture in Sweden (Swedish Board of Agriculture 2011a).

\section{Production models}

The production models studied differed in orientation (organic or conventional), winter housing of the animals (housed or outdoors), calving time (January, April or June) and breed type (light or heavy cows). The feed rations were customised for each separate production model. By combining clover-grass silage with late harvested grass silage, the feed rations were adapted to early or late pregnancy and lactation. This resulted in a clover-grass silage share of $100 \%$ when calving in January, $50 \%$ when calving in April and $25 \%$ when calving in June. In regions with good access to cheap straw (cereal-dominated areas in Gsk and $\mathrm{Ss}$ ), some models involved straw replacing grass silage. Feed rations with high levels of clovergrass silage or straw decrease the acreage needed, but simultaneously decrease the acreage-based payments. No calculations were made using grain in the feed rations of the suckler cows. The various production models in each area are described in Table 1.

Outdoor wintering of suckler cows has its limitations due to ground and climate conditions in Sweden. Wet and unfrozen ground will be damaged by trampling, especially if the cow breed type is heavy. For this reason, heavy cows were not used in the outdoor wintering calculation models. In Nn, outdoor wintering was also excluded due to uncertainties about how snow depth and predators would influence the production results. The size of each operation was taken as 100 suckler cows including replacement heifers, plus grazing and arable land sufficient for feeding these cows and replacement heifers. The farms were assumed to have no other business than the cow-calf operation, which thus had to bear all the costs of the farm business, including administration. All calves were assumed to be sold at weaning except replacement heifers.

Organic feed production differs from conventional by not using pesticides or commercial mineral fertilisers, which results in lower yields. For grassclover leys, the difference is relatively small, while it is large for grass leys which are more dependent on the nitrogen in mineral fertilisers. The yield levels used in the calculations are presented in Table 2. Grassland yields are low in Sweden compared with many other countries in Europe (Smit 2008) due to the Nordic climate and the fact that the environmental payment system does not allow semi-natural pasture to be fertilised with natural or commercial fertilisers. 
Table 1 Different production models calculated for the regions Gsk (forest districts in Götaland), Ss (plain districts in Svealand) and Nn (lower parts of Norrland)

\begin{tabular}{|c|c|c|c|c|c|c|c|c|c|c|}
\hline \multirow{3}{*}{$\begin{array}{l}\text { Production model } \\
\text { Winter housing } \\
\text { Calving month }\end{array}$} & \multicolumn{5}{|c|}{ Organic, $\mathrm{O}$} & \multicolumn{5}{|c|}{ Conventional, C } \\
\hline & \multicolumn{3}{|c|}{ Housed } & \multicolumn{2}{|c|}{ Out wintering, $\mathrm{W}$} & \multicolumn{3}{|c|}{ Housed } & \multicolumn{2}{|c|}{ Out wintering, W } \\
\hline & 1 & 4 & 6 & 4 & 6 & 1 & 4 & 6 & 4 & 6 \\
\hline Light breed type, L, $550 \mathrm{~kg}$ & $1 \mathrm{OL}$ & $4 \mathrm{OL}$ & $6 \mathrm{OL}$ & 4OLW & $6 \mathrm{OLW}$ & $1 \mathrm{CL}$ & $4 \mathrm{CL}$ & $6 \mathrm{CL}$ & 4CLW & 6CLW \\
\hline Heavy breed type, $\mathrm{H}, 700 \mathrm{~kg}$ & $1 \mathrm{OH}$ & $4 \mathrm{OH}$ & $6 \mathrm{OH}$ & & & $1 \mathrm{CH}$ & $4 \mathrm{CH}$ & $6 \mathrm{CH}$ & & \\
\hline
\end{tabular}

In each region, the calculations were made with or without access to straw. The numbers 1, 4 and 6 refer to the calving month (January, April and June, respectively)

$O$ organic production, $C$ conventional production, $L$ light cow breed $(550 \mathrm{~kg}), H$ heavy cow breed $(700 \mathrm{~kg}), W$ outdoor wintering

Basic calculation, future scenarios and sensitivity analyses

The basic calculation used 2009 data on current single farm payments, compensation grants, environmental payments and prices for weaned calves. In the future calculations, the return to labour was calculated for varying scenarios that differed regarding current agricultural politics and therefore payments, calf prices and land costs. In the scenario $\mathrm{A}$, the single farm payment was assumed to be phased out. In scenario A1, this was not compensated for, but the cost of land decreased when the market price of land was no longer influenced by the single farm payments. Without single farm payments, the opportunity cost for agricultural land is zero in the studied regions (Agriwise 2011). In scenario A2, the phased out single farm payment was compensated for by a $50 \%$ increase in the environmental payments. In scenario A3, the single farm payment stayed in place, but was perceived by the farmer as a common income for arable land, i.e. a revenue that was independent of the cow-calf operation. Grazing, on the other hand, is needed to receive the single farm payment on semi-natural pasture and was therefore seen as an enterprise-specific income in scenario A3.
Scenario B describes decreased prices on weaned calves as a result of the abolition of the male premium. By combining A1 (phased out single farm payment, not being compensated but lower cost of land) with scenario $\mathrm{B}$, scenario $\mathrm{C}$ was created. By combining A2 (phased out single farm payment plus $50 \%$ increase in environmental payments) with reduced building costs (see below), scenario D was created. The various future scenarios and their designations are described in Table 3 for the Gsk region. The same scenarios were formulated for Ss and $\mathrm{Nn}$, but payments and land costs were adjusted accordingly. Analyses were carried out to examine the effects of scaling up (200 cows), a price premium for organic beef ( $3 \mathrm{SEK} \mathrm{kg}{ }^{-1}$ slaughtered weight, assumed to result in a $10 \%$ increase in calf price) and a $25 \%$ decrease in investment cost in buildings.

Sample calculation with data

The method of calculation for the production model $4 \mathrm{OH}$, with 100 suckler cows in the Gsk area for scenario A2, is described in Table 4. The methods used for obtaining the biological, technical and economic data used in the calculation are described in footnotes to that table.

Table 2 Net forage and grazing yields (kilogram dry matter per hectare per year) for organic and conventional production in regions Gsk, Ss and Nn, according to Kumm (2009)

\begin{tabular}{lllll}
\hline & 2 Gsk and Ss organic & Conventional & Nn organic & Conventional \\
\hline Forage, 2 cuts per year, clover-grass ley & 6,480 & 7,290 & 5,200 & 5,820 \\
Forage, 1 cut per year, grass ley & 3,200 & 6,210 & 2,560 & 4,970 \\
Cultivated grazing & 1,950 & 3,340 & 1,200 & 2,050 \\
Grazing on semi-natural pastures & 1,600 & 1,600 & n.a. & n.a. \\
\hline
\end{tabular}


Table 3 Single farm payment, support for less favoured areas, environmental payments, calf prices and land costs in the basic calculation (2009) and in the various scenarios in the Gsk region $(1 \mathrm{SEK} \approx 0.10 €, 2009)$

\begin{tabular}{|c|c|c|c|c|c|c|c|c|}
\hline \multirow[b]{2}{*}{ Scenario } & \multirow{2}{*}{$\begin{array}{l}\text { Single } \\
\text { farm } \\
\text { payment } \\
\text { SEK ha }^{-1}\end{array}$} & \multirow{2}{*}{$\begin{array}{l}\text { Support for } \\
\text { less favoured } \\
\text { area } \\
\text { SEK ha } \\
\text {-1 }\end{array}$} & \multicolumn{3}{|c|}{ Environmental payments } & \multicolumn{2}{|l|}{ Calf prices } & \multirow{2}{*}{$\begin{array}{l}\text { Land cost } \\
\begin{array}{l}\text { Arable land/ } \\
\text { grazing land, } \\
\text { SEK ha }\end{array}{ }^{-1}\end{array}$} \\
\hline & & & $\begin{array}{l}\text { Grass ley, } \\
\text { SEK ha }^{-1}\end{array}$ & $\begin{array}{l}\text { Semi-natural } \\
\text { pasture, } \\
\text { SEK ha }{ }^{-1}\end{array}$ & $\begin{array}{l}\text { Organic } \\
\text { production, } \\
\text { SEK cow }^{-1}\end{array}$ & $\begin{array}{l}\text { Bulls, SEK } \\
\text { head }^{-1} \text {, light- } \\
\text { heavy breed }\end{array}$ & $\begin{array}{l}\text { Heifers, SEK } \\
\text { head }^{-1} \text {, light- } \\
\text { heavy breed }\end{array}$ & \\
\hline 2009 & 1,194 & 515 & 550 & 1,100 & 1,800 & $5,100-5,700$ & $3,400-3,900$ & $850 / 425$ \\
\hline A1 & 0 & 515 & 550 & 1,100 & 1,800 & $5,100-5,700$ & $3,400-3,900$ & 0 \\
\hline $\mathrm{A} 2$ & 0 & 515 & 825 & 1,650 & 2,700 & $5,100-5,700$ & $3,400-3,900$ & 0 \\
\hline A3 & 0 arable, 1,194 & 515 & 550 & 1,100 & 1,800 & $5,100-5,700$ & $3,400-3,900$ & $0 / 425$ \\
\hline $\mathrm{B}$ & 1,194 & 515 & 550 & 1,100 & 1,800 & $3,800-4,400$ & $3,400-3,900$ & $850 / 425$ \\
\hline $\mathrm{C}$ & 0 & 515 & 550 & 1,100 & 1,800 & $3,800-4,400$ & $3,400-3,900$ & 0 \\
\hline $\mathrm{D}$ & 0 & 515 & 825 & 1,650 & 2,700 & $5,100-5,700$ & $3,400-3,900$ & 0 \\
\hline
\end{tabular}

\section{Results}

As noted in the 'Production models' section, a large number of production models were examined. To simplify the description of the results, only the models achieving the highest return to labour in each category, organic and conventional, are included (Table 5).

In Fig. 1, the return to labour in the base year 2009 is compared with scenario A1 (decoupled single farm payments), scenario A2 (decoupled single farm payments compensated for by $50 \%$ increase in environmental payments for leys, semi-natural pasture and organic production) and scenario A3 (single farm payment on arable land seen as common income by the farmer). The stipulated farm workers wage is marked as a solid horizontal line. As can be seen in the diagram, the best alternatives in 2009 achieve a return to labour level with the stipulated farm workers wage in Gsk and Nn, but not in Ss. The conventional alternatives result in a considerably lower return to labour than the organic alternatives. In Ss, no conventional alternative can pay for any labour according to Fig. 1. The best profitability is found in alternatives $4 \mathrm{OH}$ and 4OLW, alternatives with spring calving and organic production. In the event of decoupled single farm payments (A1), the best alternatives decrease to half the stipulated farm workers wage in Gsk and $\mathrm{Nn}$ and decrease even further in Ss. If the phased out single farm payment is compensated for by $50 \%$ increased environmental payments (A2), the best alternatives in
Gsk and Nn reach a higher return to labour than the stipulated farm workers wage and the best models in Ss nearly reach this level. Scenario A3 (single farm payment in place but considered common income for arable land) has approximately the same result as the base calculation year 2009 in Gsk due to the small arable acreage in this region, where all grazing takes place on semi-natural pasture. In Ss and $\mathrm{Nn}$, where the majority of the acreage is arable land, the effect of A3 is practically the same as in A1 (decoupled single farm payment) (Fig. 1).

The generally more favourable growing conditions in Ss are not strong enough to compensate for the lower grants and this leads to lower profitability in the region compared with the other two regions. The sensitivity analyses for different models in Ss revealed that the return to labour is influenced not only by grants for different services and general growing conditions, but also by choices made by the farmer. This is illustrated in Fig. 2, where the effects of various single changes to the initial 2009 calculation are shown for region Ss. By reducing the investment costs for buildings by $25 \%$, the return to labour increases by nearly $60 \mathrm{SEK} \mathrm{h}^{-1}$ compared with model $4 \mathrm{OH}$. If an organically produced weaned calf gets a price premium of $1.50 \mathrm{SEK} \mathrm{kg} \mathrm{kg}^{-1}$ live weight (equal to $3 \mathrm{SEK} \mathrm{kg} \mathrm{Sg}^{-1}$ carcass weight), the return to labour increases by 45 SEK $\mathrm{h}^{-1}$ compared with model $4 \mathrm{OH}$. Doubling the herd size in an organic production system increases the return to labour by approximately 35 SEK $\mathrm{h}^{-1}$ (Fig. 2). 
Table 4 Method of calculating enterprise-specific income less operating costs excluding labour (SEK per cow per year) and return to labour (SEK per hour)

Enterprise-specific income

Calves

$3,700^{\mathrm{a}}$

Slaughter revenue

$1,633^{\mathrm{b}}$

Support for less favoured areas

$1,215^{\mathrm{c}}$

Environmental payment semi-natural

$3,089^{\mathrm{d}}$

pasture

Environmental payment leys

$406^{\mathrm{e}}$

Environmental payment organic production

Total enterprise-specific income

$2,687^{\mathrm{f}}$

Operating costs

Feed

$3,953^{\mathrm{g}}$

Other costs

$2,316^{\mathrm{h}}$

Building (depreciation and upkeep)

$2,152^{\mathrm{i}}$

Opportunity cost of land

$0^{\mathrm{j}}$

Interest

$1,222^{\mathrm{k}}$

3,087

Enterprise-specific income minus

operating costs excluding labour

Labour, hours

Enterprise-specific income minus operating costs per $\mathrm{h}^{-1}$

Example scenario A2 (phased out single farm payment compensated for by increased environmental payments), production model $4 \mathrm{OH}$ (April calving, organic production and heavy breed suckler cow housed in a cubicle system)

${ }^{\text {a }}$ Income from 0.28 heifer calves $\left(275 \mathrm{~kg}\right.$ at $\left.14 \mathrm{SEK} \mathrm{kg}{ }^{-1}\right)$ and 0.46 bull calves $\left(300 \mathrm{~kg}\right.$ at $19 \mathrm{SEK} \mathrm{kg}^{-1}$ ) $\mathrm{cow}^{-1}$. A light cow weans a lighter calf ( $245 \mathrm{~kg}$ heifers, $270 \mathrm{~kg}$ bulls). June calving means earlier weaning and therefore selling a $15 \%$ lighter calf compared with January or April calving (Swedish Dairy Association 2011); 0.20 heifer calves are used as replacements

${ }^{\mathrm{b}} 0.19$ cow slaughtered and 0.01 cadavers (20\% replacement), 0.01 breeding bull is slaughtered per year (in total five breeding bulls on 100 cows, with one being replaced each year). A cow or a breeding bull from a heavy breed kills out at 350 and $450 \mathrm{~kg}$, respectively. The slaughter weights for a light breed are 275 and $400 \mathrm{~kg}$, respectively (Taurus 2011). The price level is 23 SEK $\mathrm{kg}^{-1}$ carcass weight (Agriwise 2011)

${ }^{\mathrm{c}}$ The size of the support for less favoured areas is coupled to the number of animals and the acreage of leys and semi-natural pasture. The basic level in this region is 1,350 SEK ha ${ }^{-1}$ for acreages between 0 and 90 ha, on condition that there is at least 1.3 animal units (a.u.) ha ${ }^{-1}$. In Ss, the minimum level is 1.1 and in $\mathrm{Nn} 1.0$ a.u. $\mathrm{ha}^{-1}$ (Swedish Board of Agriculture 2011c). In the future scenarios, the support for less favoured areas is on the same level as in 2009

${ }^{\mathrm{d}} 1.87$ ha semi-natural pasture $\mathrm{cow}^{-1}$ (Clason 2009) is used (in total $187 \mathrm{ha})$ at the payment of $1,650 \mathrm{SEK} \mathrm{ha}^{-1}(+50 \% \mathrm{com}-$ pared with the starting point in 2009). January calving decreases the need for semi-natural pasture by $25 \%$, while June calving increases it by $10 \%$. A light breed cow lowers the grazing need by $20 \%$. In Gsk, $100 \%$ of the grazing is semi-natural pasture. In Ss, $20 \%$ of the grazing is semi-natural pasture and $80 \%$ is leys on arable land. In $\mathrm{Nn}$, all grazing is leys on arable land

${ }^{\mathrm{e}}$ The environmental payment for leys is 300 SEK ha ${ }^{-1}$ base level and 250/700/1,800 SEK ha ${ }^{-1}$ for additional levels presupposing a stocking level of 1.3/1.1/1.0 a.u. ha ${ }^{-1}$ in Gsk/Ss/Nn (Swedish Board of Agriculture 2011c). In scenario A2, the grass leys support is increased by $50 \%$

${ }^{f}$ The environmental payment for organic production is 1,600 SEK a.u. ${ }^{-1}$ providing that there is 1 ha organic arable land or 2 ha semi-natural pasture a.u. ${ }^{-1}$ (Swedish Board of Agriculture 2011c). One cow is 1 a.u. and a heifer is 0.6 a.u. In scenario A2, the organic production payments are increased by $50 \%$

${ }^{g}$ The feed costs are calculated based on input costs to produce own feed (seed, contractor) in different models with feed rations calculated by Clason (2009) and the net forage harvest in the different regions (Kumm 2009). The production costs for forage and grazing plus that bought as feedstuff (minerals, calf feed) create feed costs per cow. Of the models studied, Ss-6CLW has the lowest feed costs. In the model reported above (Gsk-4OH), 20 ha arable land are used for 100 cows to harvest good quality silage for cows and replacement heifers. For harvesting low quality silage, 29 ha of arable land are used. In the case of January calving, $15 \%$ less arable land is used and in the case of June calving $10 \%$ more. A light breed cow uses $15 \%$ less arable land than a heavy breed cow. Conventional production uses $30 \%$ less arable land due to larger harvests

${ }^{\mathrm{h}}$ Other costs include fencing, electricity, administration, breeding bull, bedding, insurance and various costs for foot trimming, cadaver removal, ear tags and quality assurance schemes (Hushållningssällskapet 2006; Agribeef 2011)

${ }^{\mathrm{i}}$ The investment costs are 36,000 SEK cow ${ }^{-1}$ (cubicle stable) (Häggström et al. 2005; index adjusted to the 2009 price level) and the investment support is $6,000 \mathrm{SEK} \mathrm{cow}{ }^{-1}$. The average depreciation period is 15 years and the cost of upkeep is $0.5 \%$, resulting in an annual depreciation and upkeep cost of 2,152 SEK. With June calving, the cost is $20 \%$ lower. In deep litter housing systems, the building costs are 300 SEK less, but bedding costs are 900 SEK cow ${ }^{-1}$ year $^{-1}$. Housing costs for organic and conventional production are the same. Construction costs for the outdoor wintering of cows (frost-free water supplies, sick boxes, handling facilities and fencing for the winter paddock) amount to 4,500 SEK cow ${ }^{-1}$, which is depreciated over 10 years (personal estimates based on experience from Swedish ranching operations)

${ }^{\mathrm{j}}$ The opportunity costs for arable land and semi-natural pasture are 0 SEK in all three regions if the single farm payment is decoupled (Agriwise 2011). In the base level calculation for 2009 , the land costs equal the tenancy fees for the region reported by the Swedish Board of Agriculture (2010b)

${ }^{\mathrm{k}}$ The interest is set at $5 \%$ for the average capital needed for buildings and $6 \%$ for animal and working capital

${ }^{1}$ The working hours stated refer to animal husbandry including pasture management. The time spent working with the animals was estimated using a calculation model (Nelson 2002) based on collected data from cow-calf operations. The working time spent managing pasture was calculated using a template created for this purpose by Hushållningssällskapet (2006). The working time in outdoor wintering systems is $17.5 \mathrm{~h} \mathrm{cow}^{-1}$ year $^{-1}$ based on data from interviews with farmers using this type of production model 
Figure 3 shows the return to labour per hour in scenario $\mathrm{C}$, a combination of lower calf prices following the abolition of the male premium and the phased out single farm payment without compensation. This can be seen as a 'worst case' scenario. Scenario D is also included in Fig. 3 as a combination of phased out single farm payment compensated for by increased environmental payments and $25 \%$ lower building costs. This can be seen as a 'best case' scenario. In the worst case scenario, the return to labour is $50 \mathrm{SEK} \mathrm{h}^{-1}$ or less. In the best case scenario, the most profitable production model is much higher than the stipulated farm workers wage. As Fig. 3 also shows, the Ss region has lower profitability in scenario 2009 and scenario D compared with regions Gsk and Nn.

\section{Discussion}

The aim was to calculate possible future economically sustainable production systems. For this reason, average production data for current, generally small, and in many cases, economically unsustainable herds were not included. Therefore, the calculations were based on data from cow-calf operations with better than average production. This includes breeding herds with high calf output (Swedish Dairy Association 2011) and large, well-managed herds with low labour demand per cow (Nelson 2002). The feed demand was theoretically calculated (Clason 2009) and optimal feed production technology was assumed (Kumm 2009). The feed consumption is higher in many cowcalf operations today due to spillage and overconsumption (Arnesson 2011). The cost of feed production is often higher than necessary due to use of sub-optimal techniques. This suggests that the results presented here are reliable and valid for costefficient future cow-calf operations, but overestimate the profitable average Swedish cow-calf herds at present.

The revenues from a specialist cow-calf operation consist of the sales of weaned calves and culled cows, the payments for environmental services and support for less favoured areas and the single farm payment. The revenue from the calves is dependent on the weaning weight and the price per kilogram obtained. The price in turn is dependent on the profitability of fattening to slaughter operations. The support for less favoured areas presupposes that the farm is situated in a supported region. The environmental payment is coupled to the classification of the grazing land; whether the farm is organic or not; and the acreage available for grazing and leys. The single payment scheme depends on where in Sweden the farm is situated and the acreage of the farm. The results of this study and those of a Delphi study based on an expert panel (Salevid 2011) suggest that payment for environmental services, support for less favoured areas and the single farm payment are determining factors for profitability. Despite only small differences in the costs of production and revenues from calves and cull cows, there are gross variations in the return to labour between the alternatives due to the differences in various EU support payments.

In a previous study of profitability among 13 specialist Swedish cow-calf operations, the total revenues consisted of $49 \%$ sales of calves and cull cows, $26 \%$ support for less favoured areas and environmental payments and $25 \%$ revenue from single farm payment schemes (Agribeef 2011). Similarly, in other European countries such as Austria, Germany, France, Spain, the UK and the Czech Republic, various grants make up

Table 5 Description of the calculated production models showing the highest return to labour within each respective category, organic and conventional production

\begin{tabular}{|c|c|c|c|c|}
\hline \multirow{2}{*}{$\begin{array}{l}\text { Production model } \\
\text { Winter housing }\end{array}$} & \multicolumn{2}{|c|}{ Organic, O } & \multicolumn{2}{|c|}{ Conventional, C } \\
\hline & Housed & Out wintering, $\mathrm{W}$ & Housed & Out wintering \\
\hline Calving month & 4 & 4 & 4 & 4 \\
\hline Light breed type, L, $550 \mathrm{~kg}$ & $4 \mathrm{OL}$ & 4OLW & $4 \mathrm{CL}$ & 4CLW \\
\hline Heavy breed type, $\mathrm{H}, 700 \mathrm{~kg}$ & $4 \mathrm{OH}$ & & $4 \mathrm{CH}$ & \\
\hline
\end{tabular}

Number 4 indicates calving in April

$O$ organic production, $C$ conventional production, $L$ light breed cows (550 kg), $H$ heavy breed cows $(700 \mathrm{~kg}), W$ outdoor wintering 
Fig. 1 Return to labour (SEK per hour) for various production models at base line year 2009 and scenarios A1, A2 and A3. The stipulated farm workers wage, $180 \mathrm{SEK}^{-1}$, is shown as a solid horizontal line

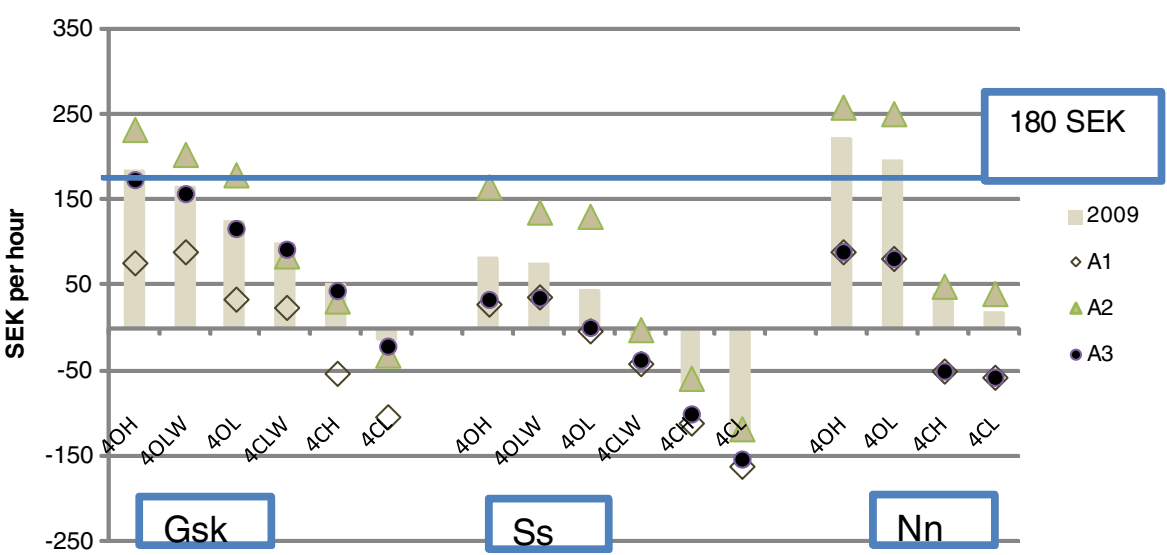

15-60\% of the total revenue in cow-calf operations. On the other hand, in countries such as Canada, the USA, Argentina and Brazil, sales of calves and cull cows make up $100 \%$ of the revenue in cow-calf operations (Agribenchmark 2011).

One threat, not only to beef production, but also to grazing management as an environmental service, is that farmers largely view the single farm payment on arable land as something they receive without having to use the land for production, such as roughage for suckler cows (scenario A3 in Fig. 1). Such a viewpoint could lead to currently active farmers phasing out their production. It could also lead to passive landowners demanding a higher tenancy fee, which could make it harder to build efficient cow-calf operations in the future. Another threat is that farmers will strive for maximised return to labour and reach the conclusion that employment outside the farm pays a substantially higher wage than the stipulated farm workers wage, which was the target in the present study. Building workers have a $25 \%$ higher salary than farm workers in Sweden (Lönestatistik 2011). Only organic production in scenarios with $50 \%$ higher environmental payments (A2 and D) can come anywhere near the building worker's wage level, according to Figs. 1 and 3. A third threat is relative price development over time. In the past 10 years, the nominal price for weaned calves has increased by only $20 \%$, while the stipulated farm workers wage has increased by $40 \%$ (Agriwise 2011). This issue of wages increasing at a faster rate than beef prices is likely to be a continuing trend over the next 10 years (OECD-FAO 2011).

There was a large variation in profitability expressed as return to labour per hour between the different production models, regions and future scenarios studied here (Figs. 1 and 3). The organic
Fig. 2 Return to labour (SEK per hour) in sensitivity analyses for $4 \mathrm{OH}$ in Ss when increasing the herd size, adding an organic price premium and reducing the investment cost of buildings

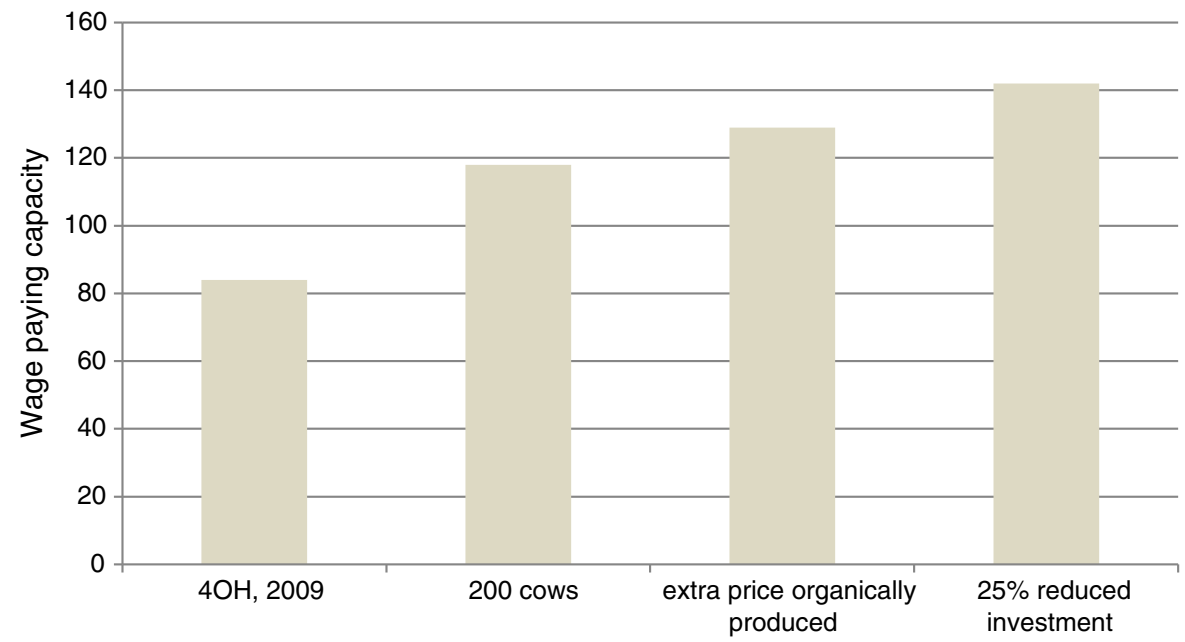


Fig. 3 Return to labour (SEK per hour) for various production models at base line year 2009 for scenarios $\mathrm{C}$ and $\mathrm{D}$. The stipulated farm workers wage, 180 SEK $\mathrm{h}^{-1}$, is shown as a solid horizontal line

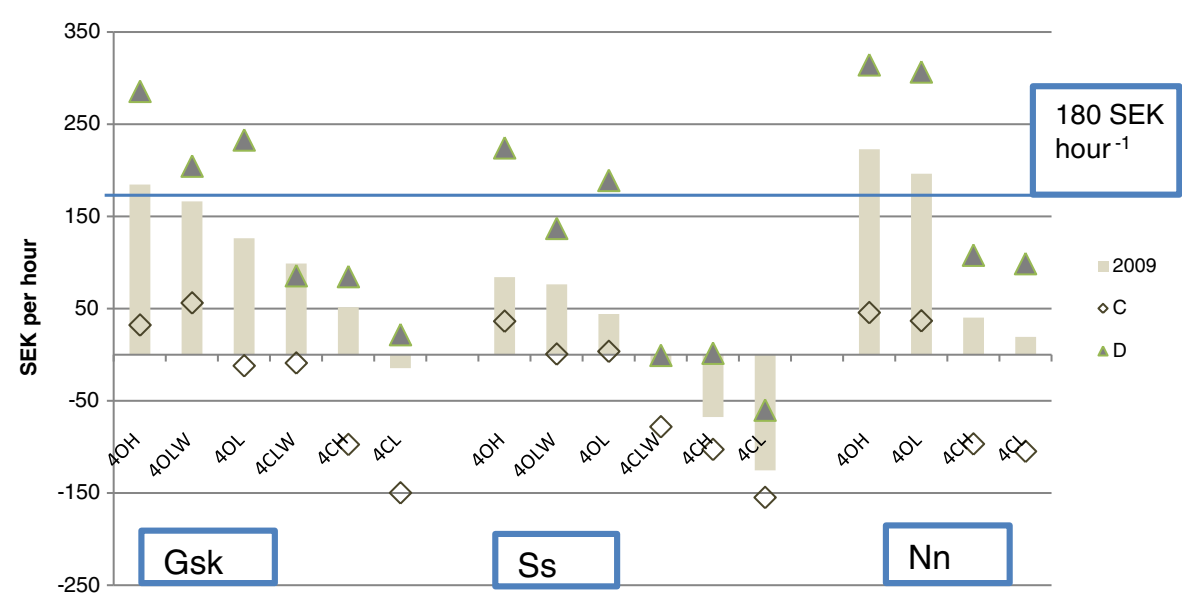

production model had consistently higher profitability than the conventional model due to the organic environmental payments and the larger acreage needed per cow because of lower feed yields. The organic environmental payment was $1,800 \mathrm{SEK} \mathrm{cow}^{-1}$ including replacements in most scenarios, which corresponds to approximately $60 \mathrm{SEK} \mathrm{h}^{-1}$ for labour if $13 \mathrm{~h}$ is spent working (Table 4 , footnote 1 ). The greater need for land in the organic alternatives also makes the level of environmental payments for leys, support for less favoured areas and single farm payments higher on a per cow basis in organic production than in conventional production. This same reason makes heavier breed cows more profitable than light breed cows, since the former need more land for feed and grazing. The most land-demanding conventional alternative, $4 \mathrm{CLW}$, had the best return to labour in the conventional group.

The forest-dominated regions of Gsk and $\mathrm{Nn}$ showed better profitability than the plains-dominated region Ss in spite of the natural growing conditions such as higher yield per hectare and the favourable farm layout in the latter region (Figs. 1 and 3). One reason for the higher profitability was the higher level of environmental payments for the semi-natural pasture in Gsk, where the whole grazing acreage was assumed to be on semi-natural pasture. In $\mathrm{Nn}$, the support for less favoured areas and the environmental payments for leys were higher per hectare than in Gsk and Ss (Table 4, footnote $\mathrm{d}$ ). In this way, the subsidy system enhances the variation in profitability and both enables and disables production in different regions. In the long run, this creates a steering mechanism with animal production in regions where the subsidy systems can ensure profitability. Future investments and generation/ownership shifts will occur where this is economically viable. The variation in profitability between different regions will accelerate specialisation towards calf production in certain regions.

In the case of the uncompensated phased out single farm payment (A1), no production model reached a return to labour wage in the level of the stipulated farm workers wage. When the phasing out was assumed to be compensated for by a $50 \%$ increase in environmental payments (A2), a few of the organic production models in Gsk and $\mathrm{Nn}$ reached the stipulated farm workers wage. When the single farm payment was assumed to remain, but to be perceived as a common income for arable land and not a part of the suckler cow revenue (A3), only one production model, $4 \mathrm{OH}$ in Gsk, reached the stipulated farm workers wage (Fig. 1).

The sensitivity analyses in Fig. 2 showed some strategic choices that could at least partly compensate for decreases in subsidies and in the market price for calves. For example, a $25 \%$ reduced investment cost in buildings increased the return to labour by $140-80$ $=60 \mathrm{SEK} \mathrm{cow}^{-1}$, provided that cheaper buildings do not increase the labour requirement. The strong effect of decreased building costs indicates that investment subsidies and changes in regulations allowing for simpler building solutions are important in this context. However, as Figs. 1 and 3 show, $60 \mathrm{SEK} \mathrm{h}^{-1}$ is not enough to reach a return to labour in line with the stipulated farm workers wage in many of the production models and future scenarios. By marketing organic beef at a premium (1.50 SEK kg $\mathrm{g}^{-1}$ live weight or 3 SEK kg ${ }^{-1}$ carcass weight) and hence creating an extra price for organic weaned calves and cull cows, the 
return to labour can be increased by approximately 45 SEK $h^{-1}$.

Doubling the herd size to 200 cows increased the return to labour in Ss by $35 \mathrm{SEK} \mathrm{h}^{-1}$ and in Gsk by 60 SEK $h^{-1}$. This is due to lower investment costs and labour requirements per cow when the herd increases. In spite of this, the majority of current Swedish cowcalf operations are with small herds in old buildings. At present, less than $2 \%$ of Swedish suckler cows are in herds of 100 cows or more (SCB 2010) and the average herd size is 16 suckler cows (Swedish Board of Agriculture 2011a). The biggest barrier to size rationalisation is the question of access to land. Even though there are unused areas of physically available semi-natural pasture and arable land that could be made into effective units for larger cow-calf operations, there are many factors limiting such development. Traditions, ownership structures of the land and the present subsidy system are some such factors.

A combination of decreased calf prices following the abolition of the male premium and a phased out single farm payment not being compensated for (scenario $\mathrm{C}$ in Fig. 3) would lead to very low or even negative levels of return to labour. On the other hand, a combination of phased out single farm payment compensated for by increased environmental payments and $25 \%$ lower building investments would result in a return to labour that equals or even exceeds the stipulated farm workers wage (scenario D Fig. 3). This is true even for region Ss, where in many other cases the profitability is very low. The results indicate that the possibility to maintain sustainable Swedish beef production and to fulfil the Swedish Environmental Objectives on grazing semi-natural pasture and organic production is dependent on the future configuration of the agricultural support systems and the increasing environmental payments.

Beef production based on grazing and feed production on arable land in forest-dominated regions does not compete with any other food production system at present and in fact could be described as changing inedible plant material into edible human food (Wilkinson 2011). Today, this kind of land is considered non-profitable for grain production and lacks an alternative value as agricultural land (Agriwise 2011). The area of agricultural land in forest regions is also decreasing (Swedish Board of Agriculture 2011a) and if the single farm payment should cease, large areas of such land will be turned into forest (Swedish Board of Agriculture 2007). In the Gsk region, where all grazing is on semi-natural pasture, the need for arable land for the most profitable alternatives $4 \mathrm{CLW}$ and $4 \mathrm{OH}$ was 0.4 to $0.5 \mathrm{ha} \mathrm{cow}^{-1}$, respectively. The need for semi-natural pasture varied between 1.7 and $1.9 \mathrm{ha} \mathrm{cow}^{-1}$, respectively, for the same alternatives. The need for arable land in the $\mathrm{Nn}$ region (where both grazing and forage production are performed on arable land) is 1.4 and 2.2 ha cow $^{-1}$ for $4 \mathrm{CH}$ and $4 \mathrm{OH}$, respectively. However, if there is a future shortage of land for the global food supply chain and/or for growing energy crops including trees to replace fossil fuels, the proposed advantage of using large areas of land per cow could change into a disadvantage. In the case of future competition for land for food production, it is preferable if the present support system keeps the land within agriculture so that it can be easily transferred into highly productive food crops.

In the case of land scarcity, the need for acreage per cow can be lessened by, amongst other things, changing grass leys to clover-grass leys, which in the organic production systems yielded twice the amount per hectare (Table 2). The winter feed in the most profitable of the production scenarios investigated $(4 \mathrm{OH})$ consisted of $60 \%$ grass silage and $40 \%$ grass-clover silage. By replacing the grass silage with clover-grass silage and purchased straw, the acreage required per cow would decrease from 0.49 to 0.24 ha in this organic production model. In the corresponding conventional production scenario using only clover-grass silage and straw $(4 \mathrm{CH})$, the need for arable land would decrease to $0.22 \mathrm{ha} \mathrm{cow}^{-1}$. The need for arable land for winter feed production could be decreased even further by delaying the calving time to June, using lighter breed cows and replacing some of the silage with grain in the feed rations. By grazing on arable leys rather than semi-natural pasture, the total acreage needed would also be lessened. On the other hand, arable land has a higher opportunity cost in the case of scarcity of land for food production.

These acreage-saving measures were not profitable in the scenarios studied here. However, with a sufficiently high opportunity cost for arable land, in combination with decreased payments per hectare, the lower acreage production models would result in higher profitability. In order for higher acreage, suckler cow-based beef production to be profitable in these conditions, a considerably higher price level for beef would be needed. According to a future study by the Swedish Board of Agriculture (2007), there will be a large transfer of 
grazing and arable land to forest in already forestdominated regions if the acreage-based support system is abolished. The Swedish peoples' willingness to pay for keeping agricultural landscape open by cereal production, grazing arable land and grazing semi-natural pasture, instead of being afforested, is estimated to be 1,600, 3,100 and 3,900 SEK ha ${ }^{-1}$ year ${ }^{-1}$, respectively, based on a contingent valuation survey by Drake (1999) recalculated for the 2009 value of the SEK. This is comparable to the combined acreage-based support payments for organic production for the majority of the scenarios studied here (Table 3). A future research task is to calculate the society-based profitability of various organic and conventional production models for suckler cow-based beef production in the event of land scarcity and environmental payments based on willingness to pay studies.

\section{Conclusions}

Given the current environmental support for organic production, it is possible to achieve a return to labour equal to the Swedish stipulated farm wage with an organic cow-calf operation of 100 suckler cows if this is situated in a region where most of the required grazing can be done on semi-natural pasture with environmental support. This profitability also requires continuation of the single farm payment system or increased support for environmental services if the single farm payment is phased out. A further prerequisite is unchanged support for less favoured areas. Profitability equal to the stipulated farm wage is also possible in regions with insufficient semi-natural pasture granted extra support for leys and less favoured areas. Conventional cow-calf operations that receive lower environmental support per hectare and use less land per cow have a considerably lower return to labour than organic operations under the present support systems. The means to support organic production are justified by the non-use of pesticides and fertilisers and the larger proportion of leys in the crop rotations as examples. The existing support model makes the differences between the regions greater than they should be without the support. There are risks that the area-based support system could cause landowners to demand higher tenancy fees, which would reduce the profitability of active farmers dependent on rented land. If scarcity of land for food and energy production should arise in the future, the cow-calf production models must change to more landefficient models. This could be achieved by replacing grass silage with clover-grass silage and purchased straw, delaying the calving time to June, using lighter breed cows or replacing some of the silage with grain. Conventional production might also be competitive in such a scenario, despite the energy demand for fertiliser production.

Acknowledgments This study was funded by the Swedish Farmers' Foundation for Agricultural Research.

Open Access This article is distributed under the terms of the Creative Commons Attribution License which permits any use, distribution, and reproduction in any medium, provided the original author(s) and the source are credited.

\section{References}

Agribeef (2011) Profitability in beef production. http://www. agribeef.se. Accessed 15 Feb 2011

Agribenchmark (2011) Beef and Sheep Report, http://www. agribenchmark.org. Accessed 15 Feb 2011

Agriwise (2011) http://www.agriwise.org/. Accessed 15 Nov 2011

Arnesson S (2011) Cow-calf production on two farms in western Sweden, Report 30, Swedish University of Agricultural Sciences, pp 13-15

Clason (2009) Consulting firm Växa Sverige, personal communication

Drake (1999) The Swedish agriculture landscape-economic characteristics, valuations and policy options. Int J Soc Econ 26:1042-1060

Ekoweb.nu (2012) Ekologisk livsmedelmarknad, Rapport om den ekologiska branchen sammanställd av ekoweb.nu 26 januari 2012, pp 19

Hushållningssällskapet (2006) Betesmarken 1.1

Häggström A. et al. (2005) LRF, Swedish Meats, LRF Konsult, WWF, Hagmarks Mistra, Taurus Vinterhållning av nötkreatur för betesdrift, Affärsmöjligheter -ekonomi och samarbete, Liggbåsstall för 100 dikor, p 5, Liggbåsstall för 200 dikor, p 6

KRAV (2012) http://www.krav.se/System/Spraklankar/ In-English/KRAV-/. Accessed 15 Jan 2012

Kumm (2009) Cost of roughage production to beef cattle, Swedish University of Agricultural Sciences, Department of Animal Environment and Health, Section of production systems, Report 23, pp 10-20

Lönestatistik (2011) http://www.lonestatistik.se/. Accessed 15 Sept 2011

Ministry of Agriculture (2004) Genomförande av EU:s jordbrukspolitik. Departementsserien Ds 2004:9

Ministry of Agriculture (2010) The rural development program for Sweden 2007-2013, version mars 2010, pp 66-67, pp 9 
Nelson (2002) Lönsamhet i olika besättningsstorlekar i olika produktionsmodeller, Skogs- och Lantarbetsgivareförbundet, SLA Analysgrupp

Nilsson (2007) Ekologisk produktion och miljökvalitétsmålenen litteraturgenomgång. CUL, Swedish University of Agricultural Sciences, pp 1-2

OECD-FAO (2011) Agricultural outlook 2011-2020. http:// www.fenalce.org/archivos/agricoutlook2020.pdf. Accessed 15 Sept 2011

Salevid (2011) Searching for economically sustainable Swedish beef production systems based on suckler cows after decoupling EU income support. Outlook Agric 40:131-138

SCB (2011) Sveriges officiella statistik, Statistiska meddelanden, Food sales 2010, Livsmedelsförsäljning inom detaljhandeln, HA 24 SM 1101, pp 12-14

SCB (2010) teknisk rapport 2010-05-21, Selander, Brundell, Avdelningen för regioner och miljö, Processavdelningen, Undersökning av företag med dikor/amkor, pp 835

Smit (2008) Spatial distribution of grassland productivity and land use in Europe. Agric Syst 98(2008):208219

Swedish Board of Agriculture (2007) Jordbrukets miljöeffekter 2020 - en framtidsstudie, 2007:7

Swedish Board of Agriculture (2008) Prisutveckling och lönsamhet inom ekologisk produktion. Rapport 10:27
Swedish Board of Agriculture (2010a), Hur styr miljöersättningarna för ekologisk produktion? - effekter på marknad och miljö, Rapport 2010:1, pp 5, pp 51: Table 12

Swedish Board of Agriculture (2010b) Agicultural Rents 2010, JO39SM1101, Table 2

Swedish Board of Agriculture (2011a) Yearbook of Agricultural Statistics 2011, Chapter 3 Utilization of arable land, Table 3.1, Chapter 6 livestock, Table 6.1, Chapter 11 Organic farming, Chapter 15 Manufacturing, Table 15.1

Swedish Board of Agriculture (2011b) Jordbruksverkets statistikdatabas http://statistik.sjv.se/Database/Jordbruksverket/ databasetree.asp. Konsumtion av livsmedel. Accessed Dec 2011

Swedish Board of Agriculture (2011c) http://www.sjv.se/ amnesomraden/stod. Accessed Feb 2011

Swedish Dairy Association (2011) Medelvärden av korrigerade 200-dagars vikter. http://www.taurus.mu/aciro/bilddb/ objektvisa.asp. Accessed 15 Jan 2011

Swedish National Atlas (2011) The Royal Swedish Academy of Agriculture and Forestry, Agriculture and Forestry in Sweden since 1900, pp 62, 78, 88-89

Taurus (2011) http://www.taurus.mu/aciro/bilddb/objektvisa.asp. Accessed 15 Feb 2011

Wilkinson (2011) Re-defining efficiency by feed used by livestock. Animal 5(7):1014-1022 